\title{
Preparation of a sulfated exopolysaccharide (S-EPS) from Ophiocordyceps sinensis fungus and its antioxidant effects
}

\author{
Tran Minh Trang, Nguyen Thi Xuan Phuong, Nguyen Thi Lai, Le Thi Thuy Hang, \\ Huynh Thu, Dinh Minh Hiep
}

Tóm tắt-Sulfated exopolysaccharides have been well-known to enhance biological activities. Exopolysaccharide (EPS) produced by Ophiocordyceps sinensis fungus is a source of natural compounds. The aim of our study is to improve the EPS biological activities by its sulfated modification using the chlorosulfonic acid (CSA)-pyridine (Pyr) method. The appropriate conditions of the sulfation reaction were explored, including $\mathrm{CSA} / \mathrm{Pyr}$ ratio (v/v) of $1: 3$ and $6 \mathrm{~h}$. The degree of substitution (DS) of S-EPS 11 was the highest $(\mathrm{DS}=1.59)$. The total contents of polysaccharides and $\mathrm{SO}_{4}{ }^{2-}$ of S-EPS 11 were $52.25 \%$ and $47.15 \%$, respectively. Besides, the FT-IR spectra analysis indicated the presence of C$O-S$ (peak of $815 \mathrm{~cm}^{-1}$ ) and $S=O$ (peak of $1129 \mathrm{~cm}^{-1}$ ) stretching vibrations, while the natural EPS did not appear. Importantly, $\mathrm{OH}^{\bullet}$ and $\mathrm{ABTS}^{\bullet}$ radical scavenging potential of S-EPS 11 significantly increased compared with those of the natural EPS. Together, we successfully generated sulfated EPS extracted from $O$. sinensis fungus which enhanced antioxidant activities of natural EPS.

Tù khóa-Antioxidant activity, Ophiocordyceps sinensis, exopolysaccharide, sulfated modification, FT-IR spectra analysis

Received : 21-09-2017; Accepted: 02-11-2017; Published: 1510-2018.

Author Tran Minh Trang*, Nguyen Thi Xuan Phuong, Nguyen Thi Lai - HCMC University of Science, VNUHCM, Vietnam;

Author Le Thi Thuy Hang - HCMC University of Food Industry, Vietnam;

Author Huynh Thu - Ho Chi Minh City University of Technology, VNUHCM, Vietnam;

Author Dinh Minh Hiep - Management Board of HCMC

Hi-Tech Agricultural Park, Vietnam;

(Email: trangbio.hcmus@gmail.com)

\section{INTRODUCTION}

phiocordyceps sinensis (syn. Cordyceps
sinensis), an insect-parasitic fungus, is known as a natural source in Chinese traditional medicine [1-3]. Major bioactive compounds from $O$. sinensis including adenosine, cordycepin, polysaccharides, proteins and amino acids, are reported to have antioxidant activity, antiinflammatory, anti-tumor and immunomodulatory [3, 4]. Among them, polysaccharide/exopolysaccharides represented as one of the most prominent compounds of antioxidants, especially the crude expolysaccharides (EPS) isolated from the $O$. sinensis culture broth $[5,6]$. To improve such of activities, sulfation has widely applied to modify the natural polysaccharides $[7,8]$.

Sulfated modification is an effective method to increase the biological activities of polysaccharides. It enhances the water solubility of polysaccharides due to the presence of polyanionic charges that which leads to increasing of absorption and application as functional foods [2]. In addition, recent studies have demonstrated that sulfated polysaccharides increased remarkable bioactivities such as antitumor, antiviral, anticoagulant and antithrombotic [2, 3]. For instance, Yan et al. obtained four sulfated EPS-1 derivatives of $C$. sinensis fungus by using chlorosulfonic acid (CSA)-pyridine (Pyr) method [2]. The results showed that the antioxidant properties of these derivatives for $\mathrm{OH}^{*}$ and ABTS radical scavenging potentials considerably rose compared to non-sulfated EPS-1. Similarly, the 
immunomodulatory activity of macrophages of a sulfated polysaccharide $\left(\mathrm{S}_{-} \mathrm{CP}_{1-8}\right)$ from Cyclocarya paliurus was also significantly improved [9]. However, the bioactivities were closely related to their physicochemical features, such as molecular weight (M.W.) and sulfate contents, in which antioxidant activity of sulfated derivatives were correlated with increasing sulfate contents, but decreasing M.W. [2, 10].

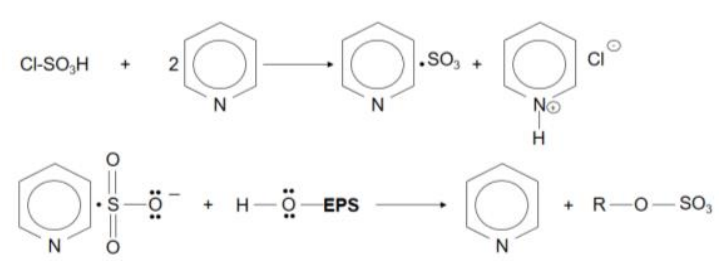

Fig. 1. The reaction mechanism for sulfation of EPS by CSA/Pyr

Currently, sulfated modification of polysaccharides was performed by a variety of various methods, including oleum dimethylformamide, sulfur trioxide pyridine $\left(\mathrm{SO}_{3}-\right.$ Pyr), chlorosulfonic acid (CSA)-pyridine (Pyr) and aminosulfonic acid (ASA)- pyridine (Pyr) method $[2,8,11,12]$. Of those, the CSA-Pyr method has widely used due to capacity of the high yield and degree of substitution (DS) [13]. The sulfated reaction underwent two steps (Fig. 1), consisting of $\mathrm{SO}_{3}-\mathrm{Pyr}$ complex and sulfated derivative formation [2]. The yield and DS depended on CSA/Pyr ratio, reaction time and temperature [14]. Specifically, the antioxidant properties of these derivatives and DS interrelate closely [2]. In this study, we obtained sulfated EPS iosolated from $O$. sinensis fungus by CSA-Pyr method. In addition, the enhancement of the sulfated EPS in free radical scavenging potentials was experimented as well.

\section{MATERIAL AND METHODS}

\section{Fungal strain and cultivation}

O. sinensis strain was obtained from Dr. Truong Binh Nguyen as a kind gift (Dalat University, Vietnam). The strain was maintained on potato dextrose agar (PDA) $(200 \mathrm{~g} / \mathrm{L}$ potatoes, $50 \mathrm{~g} / \mathrm{L}$ glucose and $15 \mathrm{~g} / \mathrm{L}$ agar, initial $\mathrm{pH}$ 7.0) at $4{ }^{\circ} \mathrm{C}$. To harvest liquid broth and biomass, the fungus was inoculated ( $4 \%$ of seed) in a medium containing $200 \mathrm{~g} / \mathrm{L}$ potatoes, $50 \mathrm{~g} / \mathrm{L}$ saccharose, $4 \mathrm{~g} / \mathrm{L}$ yeast extract, $6 \mathrm{~g} / \mathrm{L}$ peptone, $0.5 \mathrm{~g} / \mathrm{L} \mathrm{KH}_{2} \mathrm{PO}_{4}$ and $0.1 \mathrm{~g} / \mathrm{L} \mathrm{MgCl} 2$, initial $\mathrm{pH} 7.0$, at $22{ }^{\circ} \mathrm{C}$ for 40 days.

\section{Preparation of exopolysaccharide}

Liquid broth was separated after harvesting the mycelial biomass and filtered through Whatman filter paper No.1. Filtrate was concentrated in a rotary vacuum evaporator at $65^{\circ} \mathrm{C}$. recipitated with 4 volumes of $96 \%$ ethanol (v/v) overnight at $4{ }^{\circ} \mathrm{C}$ and centrifuged at $8000 \mathrm{rpm}$ for $10 \mathrm{~min}$. The precipitation was washed 2-3 times with $96 \%$ ethanol and acetone prior to lyophilizing.

EPS was optimally deproteinized by using trichloroacetic acid (TCA), hydrochloric acid $(\mathrm{HCl})$ or Sevag reagent (1-butanol : chloroform = $1: 4, \mathrm{v} / \mathrm{v})$. The EPS was then lyophilized and further purified by Sephadex-G100 (Ф2.4 x 100 $\mathrm{cm}$ ) equilibrated with $0.2 \mathrm{M} \mathrm{NaCl}$. EPS fractions were dialyzed against distilled water by using a dialysis membrane (molecular weight cut-off of $2 \mathrm{kDa}$ ) for $48 \mathrm{~h}$, and then lyophilized. Total polysaccharide and protein content were measured by the phenol - sulfuric acid (at $490 \mathrm{~nm}$ ) and Bradfrod (at $595 \mathrm{~nm}$ ) method. [5]

\section{Sulfated modification of expolysaccharide}

\section{Experimental design}

13 conditions were designed according to the table 1 with three factors, including CSA/Pyr ratio $(\mathrm{v} / \mathrm{v})$, temperature $\left({ }^{\circ} \mathrm{C}\right)$ and time $(\mathrm{h})[15]$.

Table 1. The modification conditions, yield, DS and carbohydrate content of S-EPS

\begin{tabular}{|c|c|c|c|}
\hline S-EPS & $\begin{array}{c}\text { CSA/Pyr ratio } \\
(\mathbf{v} / \mathbf{v})\end{array}$ & $\begin{array}{c}\text { Temperature } \\
\left({ }^{\circ} \mathbf{C}\right)\end{array}$ & $\begin{array}{c}\text { Time } \\
(\mathbf{h})\end{array}$ \\
\hline S-EPS & $3: 1$ & 45 & 4 \\
\hline S-EPS $_{2}$ & $3: 1$ & 65 & 2 \\
\hline S-EPS $_{3}$ & $3: 1$ & 65 & 6 \\
\hline S-EPS $_{4}$ & $3: 1$ & 85 & 4 \\
\hline S-EPS $_{5}$ & $1: 1$ & 45 & 2 \\
\hline S-EPS $_{6}$ & $1: 1$ & 45 & 6 \\
\hline
\end{tabular}




\begin{tabular}{|c|c|c|c|}
\hline S-EPS $_{7}$ & $1: 1$ & 65 & 4 \\
\hline S-EPS & $\begin{array}{c}\text { CSA/Pyr ratio } \\
(\mathbf{v} / \mathbf{v})\end{array}$ & $\begin{array}{c}\text { Temperature } \\
\left({ }^{\circ} \mathbf{C}\right)\end{array}$ & $\begin{array}{c}\text { Time } \\
(\mathbf{h})\end{array}$ \\
\hline -EPS8 & $1: 1$ & 85 & 2 \\
\hline S-EPS9 & $1: 1$ & 85 & 6 \\
\hline S-EPS10 & $1: 3$ & 45 & 4 \\
\hline S-EPS11 & $1: 3$ & 65 & 6 \\
\hline S-EPS12 & $1: 3$ & 65 & 2 \\
\hline S-EPS13 & $1: 3$ & 85 & 4 \\
\hline
\end{tabular}

Where, S\% is the sulfur content of sulfated derivatives. For Fourier Transform Infrared Spectroscopy (FT-IR) analysis, samples were recorded on a Perkin-Elmer Spectrum One Spectrometer in the region between 400 and $4000 \mathrm{~cm}^{-1}$.

\section{In vitro antioxidant activities}

\section{$A B T S^{\circ-}$ radical scavenging assay}

The ABTS $^{-}$- radical scavenging assay was measured according to the previous method with minor modifications [18]. Briefly, ABTS - was generated by mixing $7 \mathrm{mM}$ ABTS stock solution with $2.45 \mathrm{mM} \mathrm{K} \mathrm{K}_{2} \mathrm{~S}_{8}$ in a $1: 1(\mathrm{v} / \mathrm{v})$ ratio and

\section{Preparation of sulfation reagent}

CSA was added dropwise into Pyr filled in three-necked flask, with stirring and cooling in an ice water bath $[2,14]$. The ratio of CSA to Pyr referred to table 1 . The process was completed within $40 \mathrm{~min}$ and sulfation reagents were obtained.

\section{Sulfation reaction}

EPS powder $(300 \mathrm{mg})$ was suspended in anhydrous dimethyl formamide (DMF) and stirred for $30 \mathrm{~min}$ at room temperature. The sulfated EPS reaction was performed by adding sulfation reagent during stirred according to various conditions as table 1. After indicated time of reaction, the mixture was slowly cooled to room temperature, neutralized with $2.5 \mathrm{M} \mathrm{NaOH}$ and precipitated with 4 volumes of $96 \%$ ethanol (v/v). The pellet was harvested, washed, redissolved and dialyzed against distilled water for $72 \mathrm{~h}$ to remove pyridine, salt and degraded compounds. The products were finally collected by lyophilizing. [2, 12, 14].

\section{Analysis of S-EPS}

The content of polysaccharide was determined by the phenol-sulphuric acid method, using saccharose as a standard. The sulfur content of S-EPS was determined by the method of Terho and Hartiala [16], with sodium sulfate as a standard. The DS was calculated according to the equation $[15,17]$ :

$$
\mathrm{DS}=\frac{1.62 \times \mathrm{S} \%}{32-1.02 \times \mathrm{S} \%}
$$

(Equa. 1)

stored in the dark at room temperature for $10-16 \mathrm{~h}$. The solution was diluted with PBS buffer ( $\mathrm{pH}$ 7.4) to an absorbance of $0.70 \pm 0.02$ at $734 \mathrm{~nm}$. The reaction was initiated by adding $3 \mathrm{~mL}$ of ABTSsolution to $0.1 \mathrm{~mL}$ of samples. After $30 \mathrm{~min}$ incubation, the absorbance was measured at the wavelength of $734 \mathrm{~nm}$. The control experiments were conducted by replacing of $0.1 \mathrm{~mL}$ sample by $0.1 \mathrm{~mL}$ distilled water. Ascorbic acid was used as a standard. The scavenging percentage of the samples was calculated by using the following equation:

$$
\mathrm{I} \%=\frac{\mathrm{A}_{\text {control }}-\mathrm{A}_{\text {sample }}}{\mathrm{A}_{\text {control }}} \times 100
$$

(Equa. 2)

\section{$\mathrm{OH}^{*}$ radical scavenging assay}

The hydroxyl radical scavenging assay was measured according to the previous method with minor modifications [12]. The mixture consists of $1 \mathrm{~mL}$ of $\mathrm{FeSO}_{4}(3 \mathrm{mM}), 0.35 \mathrm{~mL}$ of $\mathrm{H}_{2} \mathrm{O}_{2}(3 \mathrm{mM})$, $0.3 \mathrm{~mL}$ of $\mathrm{Na}_{2} \mathrm{~S}_{2} \mathrm{O}_{8}(40 \mathrm{mM})$ and $1 \mathrm{~mL}$ of sample with different concentrations which was incubated at room temperature for $1 \mathrm{~h}$. The absorbance was then measured at the wavelength of $562 \mathrm{~nm}$. Ascorbic acid was used as a standard. The scavenging percentage was determined by using the following equation:

$$
\mathrm{I} \%=\frac{\mathrm{A}_{\text {control }}-\mathrm{A}_{\text {sample }}}{\mathrm{A}_{\text {control }}} \times 100
$$

(Equa. 3)

\section{Statistical analysis}

All data were analyzed by one-way analysis of variance (ANOVA) using SPSS software (Ver. 20). 
All experiments were performed in triplicate. A p-value $<0.05$ was considered to be statistically significant.

\section{RESULTS AND DISCUSSION}

\section{Preparation of exopolysaccharide}

The EPS crude has reported containing polysaccharides (64.96\%), proteins (12.72\%) and others $(22.32 \%)$ [5]. The protein molecules exist either in free forms [19] or polysaccharide-protein complex [20]. These properly shield and block functional groups, especially the hydroxyl groups of the polysaccharide chain, that prevents the sulfation process. Hence, the deproteinization of EPS was necessary to remove protein from EPS and enhance the yield of the sulfated EPS modification.

Table 2. Comparison of three different deproteinization methods

\begin{tabular}{|c|cc|c|cc|}
\hline $\begin{array}{c}\text { Parameters, } \\
\text { unit }\end{array}$ & \multicolumn{3}{|c|}{ Methods } \\
\cline { 2 - 6 } & TCA & \multicolumn{1}{|c|}{ HCl } & \multicolumn{2}{|c|}{ Sevag } \\
\hline Isolation yield & 25.62 & \pm & 28.77 & 42.98 & \pm \\
$(\%)$ & $1.45^{\mathrm{a}}$ & $\pm 4.23^{\mathrm{a}}$ & $3.19^{\mathrm{b}}$ & \\
\hline Deproteinization & 91.64 & \pm & 90.60 & 87.70 & \pm \\
$(\%)$ & $1.22^{\mathrm{a}}$ & & $\pm 1.88^{\mathrm{a}}$ & $0.45^{\mathrm{a}}$ & \\
\hline Polysaccharide & $76.85 \quad \pm$ & 76.92 & 62.25 & \pm \\
loss (\%) & $3.70^{\mathrm{a}}$ & & $\pm 0.87^{\mathrm{a}}$ & $3.45^{\mathrm{b}}$ & \\
\hline
\end{tabular}

Average values in a row with the same letter(s) above them do not differ significantly (Duncan test, $p<0.05$ )

Our results revealed that the Sevag method was the best technique for deproteinization of the EPS (table 3). Although the rate of deproteinization of the Sevag method was not different in comparison to $\mathrm{HCl}$ and TCA method, the isolation yield of EPS was the highest (about $42.98 \%$ ) and the polysaccharide loss was the lowest (about 62.25\%). Therefore, Sevag method was used for deproteinization of EPS in further.

The physicochemical and structural features of a polysaccharide include monosaccharide composition, carbohydrate and protein content, molecular weight, type of glycosidic linkage, and sequence of monosaccharide, etc [4]. These would affect the bioactivities and chemical modification of EPS extracted from the cultured $O$. sinensis. Thus, the comprehension of these properties of EPS would help qualitative management of material resource for the sulfation process.
Expectedly, the main composition of our EPS was polysaccharide, which occupied about $68.81 \%$ (table 3 ). It strongly agrees with the previous studies demonstrated that polysaccharide content of EPS accounted for an outnumbered majority ranging from $60 \%$ and $85 \%$. For example, EPS extracted from another $O$. sinensis strain cultured broth contained $83.9 \%$ of polysaccharides and $11.8 \%$ of proteins [21]; $65 \%$ $-70 \%$ of polysaccharides and $25 \%$ of proteins [22]; $70 \%$ of polysaccharides and $20 \%-25 \%$ of proteins [23]. By contrast, only light amount of proteins (approximate $0.19 \%$ ) appears in our EPS samples indicated that the deproteinization using the Sevag method has done. Noticeably, these differences were due to various fungus train, cultured conditions and compositions as well as the extraction technique.

Table 3. Physicochemical characterization of EPS and S-EPS 11

\begin{tabular}{|l|l|l|}
\hline \multicolumn{1}{|c|}{ Parameters, unit } & \multicolumn{1}{|c|}{ EPS } & \multicolumn{1}{|c|}{ S-EPS } \\
\hline $\mathbf{1 1}$ \\
\hline $\begin{array}{l}\text { Polysaccharide } \\
\text { content (\%) }\end{array}$ & $68.81 \pm 3.9^{\mathrm{a}}$ & $52.25 \pm 8.45^{\mathrm{b}}$ \\
\hline Protein content (\%) & $0.185 \pm 0.004$ & No detected \\
\hline Sulfate content (\%) & No detected & $47.15 \pm 1.96$ \\
\hline Main chemical groups & $\begin{array}{l}\text {-OH, C-H, } \\
\text { C-O-C }\end{array}$ & $\begin{array}{l}-\mathrm{OH}, \mathrm{C}-\mathrm{H}, \mathrm{C}-\mathrm{O}-\mathrm{C}, \\
\text { S=O, C-O-S }\end{array}$ \\
\hline Number of fractions & EPS-1; EPS-2 & S-EPS ${ }_{11}-1$ \\
\hline
\end{tabular}

Average values in a row with the same letter $(s)$ above them do not differ significantly (Duncan test, $p<0.05$ )

In addition, the FT-IR spectra analysis of EPS were also performed as shown in fig. $2 \mathrm{~A}$. The bands in the range of $3600-3000 \mathrm{~cm}^{-1}, 3000-$ $2800 \mathrm{~cm}^{-1}, 1700-1500 \mathrm{~cm}^{-1}$ and $1200-700 \mathrm{~cm}^{-1}$ corresponded with the absorption of polysaccharide chain [17]. The strong peak at $3386 \mathrm{~cm}^{-1}$ indicated stretching vibration of $\mathrm{O}-\mathrm{H}$ groups and the band at $2993 \mathrm{~cm}^{-1}$ was $\mathrm{C}-\mathrm{H}$ stretching [17, 24]. The bands at $1603 \mathrm{~cm}^{-1}$ and $1416 \mathrm{~cm}^{-1}$ suggested the presence of some residual proteins and $\mathrm{O}-\mathrm{H}$ groups of phenolic compounds, respectively. At $1051 \mathrm{~cm}^{-1}$ peak represented C-O-C stretching [25, 26]. The stretching vibrations of $\mathrm{S}=\mathrm{O}$ and $\mathrm{C}-\mathrm{O}-\mathrm{S}$ did not appeare in the natural EPS sample. 


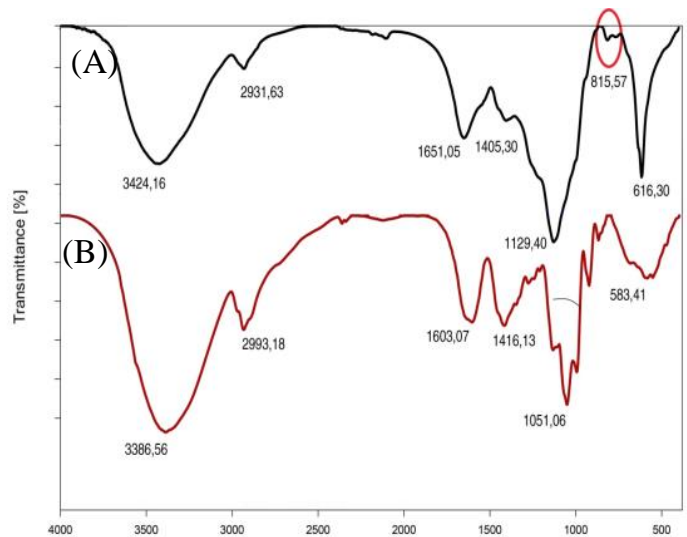

Fig 2. FT-IR analysis of S-EPS 11 (A) and EPS (B)

Furthermore, the gel filtration chromatography on Sephadex G-100 showed that EPS had two fractions, namely EPS-1 and EPS-2 (fig. 3, table 3).

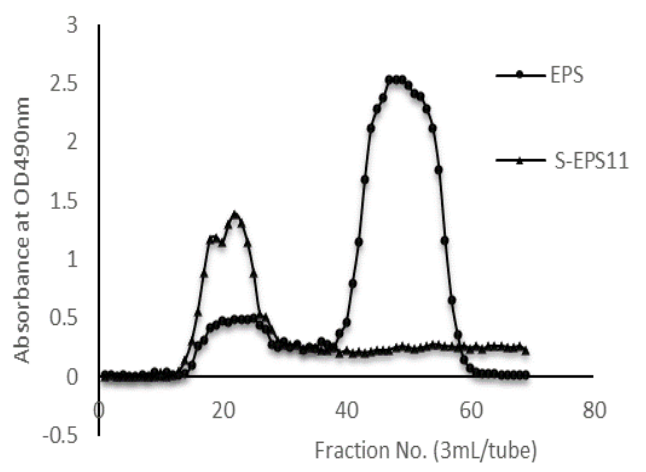

Fig 3. Elution profiles of EPS and S-EPS ${ }_{11}$ in Sephadex G-100 chromatography. Elution was analyzed by measuring the absorbance at $490 \mathrm{~nm}$ for carbohydrate

This was also an important parameter to qualitative management of EPS extracted from $O$. sinensis cultured broth.

Table 4. The yield, DS and carbohydrate content of S-EPS

\begin{tabular}{|c|c|c|c|c|c|c|}
\hline S-EPS & $\begin{array}{c}\text { CSA/Pyr } \\
\text { ratio }(v / v)\end{array}$ & $\begin{array}{l}\text { Temperature } \\
\left({ }^{\circ} \mathrm{C}\right)\end{array}$ & $\begin{array}{c}\text { Time } \\
\text { (h) }\end{array}$ & DS & Yield (mg) & $\begin{array}{c}\text { Carbohydrate content } \\
(\%)\end{array}$ \\
\hline S-EPS ${ }_{1}$ & $3: 1$ & 45 & 4 & $0.96 \pm 0.04^{\mathrm{bc}}$ & $44.49 \pm 0.69$ bcd & $30.41 \pm 0.16^{\mathrm{d}}$ \\
\hline S-EPS ${ }_{2}$ & $3: 1$ & 65 & 2 & $0.80 \pm 0.05^{\mathrm{b}}$ & $51.12 \pm 14.92^{\mathrm{de}}$ & $14.84 \pm 0.14^{\mathrm{bc}}$ \\
\hline S-EPS ${ }_{3}$ & $3: 1$ & 65 & 6 & $0.31 \pm 0.02^{\mathrm{a}}$ & $29.90 \pm 1.45^{\mathrm{ab}}$ & $12.54 \pm 2.34^{\mathrm{bc}}$ \\
\hline S-EPS 4 & $3: 1$ & 85 & 4 & $0.32 \pm 0.02^{\mathrm{a}}$ & $18.26 \pm 3.20^{\mathrm{a}}$ & $4.80 \pm 0.03^{\mathrm{a}}$ \\
\hline $\mathrm{S}_{-\mathrm{EPS}_{5}}$ & $1: 1$ & 45 & 2 & $0.86 \pm 0.04^{b}$ & $81.36 \pm 8.18^{\mathrm{h}}$ & $8.73 \pm 1.58^{\mathrm{abc}}$ \\
\hline S-EPS $_{6}$ & $1: 1$ & 45 & 6 & $1.22 \pm 0.07^{\mathrm{c}}$ & $64.46 \pm 4.50^{\mathrm{e}}$ & $11.25 \pm 0.93^{\mathrm{c}}$ \\
\hline $\mathrm{S}^{-\mathrm{EPS}_{7}}$ & $1: 1$ & 65 & 4 & $0.77 \pm 0.29^{b}$ & $77.09 \pm 20.53^{\mathrm{f}}$ & $16.16 \pm 1.46^{\mathrm{c}}$ \\
\hline S-EPS 8 & $1: 1$ & 85 & 2 & $0.43 \pm 0.10^{\mathrm{a}}$ & $46.87 \pm 11.30^{\mathrm{cd}}$ & $13.3 \pm 1.54^{\mathrm{bc}}$ \\
\hline $\mathrm{S}^{-E S_{9}}$ & $1: 1$ & 85 & 6 & $0.83 \pm 0.20^{\mathrm{b}}$ & $43.80 \pm 1.57^{\mathrm{bcd}}$ & $14.47 \pm 0.11^{\mathrm{bc}}$ \\
\hline $\mathrm{S}^{-E^{\prime}} \mathrm{S}_{10}$ & $1: 3$ & 45 & 4 & $1.04 \pm 0.26^{\mathrm{bc}}$ & $105.86 \pm 0.79^{\mathrm{g}}$ & $17.02 \pm 2.34^{\mathrm{c}}$ \\
\hline S-EPS ${ }_{11}$ & $1: 3$ & 65 & 6 & $1.59 \pm 0.09^{\mathrm{d}}$ & $41.36 \pm 5.39^{\mathrm{bcd}}$ & $52.25 \pm 8.45^{\mathrm{f}}$ \\
\hline S-EPS $_{12}$ & $1: 3$ & 65 & 2 & $0.20 \pm 0.04^{\mathrm{a}}$ & $31.34 \pm 6.03^{\mathrm{abc}}$ & $37.94 \pm 2.78^{\mathrm{e}}$ \\
\hline S-EPS $_{13}$ & $1: 3$ & 85 & 4 & $1.03 \pm 0.09^{\mathrm{bc}}$ & $25.96 \pm 6.86^{\mathrm{a}}$ & $50.28 \pm 3.42^{\mathrm{f}}$ \\
\hline
\end{tabular}

Average values in a column with the same letter( $s$ ) above them do not differ significantly (Duncan test, $p<0.05$ )

Furthermore, most of S-EPS, their carbohydrate contents decreased compared to the EPS sample (table 4). Of those, that of from S-EPS ${ }_{1}$ to S-EPS 9 significantly dropped between $38 \%$ and $60 \%$ in comparison with the natural EPS. This result is similar to the previous study demonstrating that the polysaccharide chain was hydrolyzed by a high CSA/Pyr ratio [15]. In contrast, only a part of carbohydrate of S-EPS 11 was removed approximately $16 \%$ due to decreasing the
CSA/Pyr ratio in reaction. From the above data, we suggest the optimal condition for sulfation of the EPS was CSA/Pyr ratio $=1: 3$, at $65{ }^{\circ} \mathrm{C}$ and $6 \mathrm{~h}$. Therefore, S-EPS 11 was selected to further study.

The physicochemical properties of S-EPS $S_{11}$ were determined to assess the efficiency of the sulfation modification (table 3 ). The sulfate content of S-EPS 11 significantly increased about $47.15 \%$ compared to the natural EPS (table 4). 
Notably, the FTIR analysis indicated that S-EPS ${ }_{11}$ had the presence of C-O-S (at $815 \mathrm{~cm}^{-1}$ ) and $\mathrm{S}=\mathrm{O}$ (at $1129 \mathrm{~cm}^{-1}$ ) stretching vibrations (fig. 2B) [4, 12, 28]; meanwhile, natural EPS did not. This demonstrated that we sucessfuly synthesize sulfated EPS from $O$. sinensis fungus. Besides, S-EPS ${ }_{11}$ had only one fraction, namely S-EPS $S_{11-1}$ (fig. 3) because EPS-2 fraction could be hydrolyzed by redundant CSA in the sulfation process.

\section{Antioxidant of sulfated EPS from $O$. sinensis}

To examine the enhancement of biological activities of S-EPS 11 compared with the natural EPS, we performed in vitro the antioxidant activity using the $\mathrm{OH}^{*}$ and $\mathrm{ABTS}^{\circ}$ radical scavenging assays (table 5). Expectedly, the ABTS ${ }^{\cdot}$ radical scavenging potential of S-EPS ${ }_{11}$ at concentration of $4000 \mu \mathrm{g} / \mathrm{mL}$ rose from $62.94 \%$ (the natural EPS) to $98.02 \%$. It is highly superior to four S-EPS derivatives of the previous study of Yan et al.; the figure for SEPS-1D was only about $60 \%$ [2]. Evidently, the DS of S-EPS 11 was higher than that of SEPS-1D, 1.59 and 1.38, respectively. Noticeably, there was a double increase in the $\mathrm{OH}^{*}$ scavenging ability from $46.03 \%$ to $95.24 \%$ between EPS and S-EPS 11 . The results strongly agree with $\mathrm{Ma}$ et al. reported that antioxidant activity of sulfated polysaccharides were correlated with increasing sulfate contents and DS of products [10]. Collectively, our results revealed that the sulfated EPS reliably increase the bio-activities of EPS extracted from $O$. sinensis culture broth.

Table 5. Comparison of antioxidant activities of EPS and S-EPS 8

\begin{tabular}{|c|c|c|}
\hline \multirow{2}{*}{ Samples } & \multicolumn{1}{|c|}{$\begin{array}{l}\text { The rate of free radical scavenging } \\
\text { capacity at the concentration of } \mathbf{4 0 0 0} \boldsymbol{\mu g} / \mathbf{m L} \\
(\%)\end{array}$} \\
\cline { 2 - 3 } & $\mathbf{A B T S}^{\cdot}$ & $\mathbf{O H}^{\bullet}$ \\
\hline EPS & $62.94 \pm 0.05^{\mathrm{a}}$ & $46.03 \pm 0.08^{\mathrm{a}}$ \\
\hline $\begin{array}{c}\text { S- } \\
\mathrm{EPS}_{11}\end{array}$ & $98.02 \pm 0.00^{\mathrm{b}}$ & $95.24 \pm 0.06^{\mathrm{b}}$ \\
\hline
\end{tabular}

Average values in a column with the same letter(s) above them do not differ significantly (Ducan test, $p<0.05$ )

\section{CONCLUSION}

We successfuly synthesized sulfated EPS extracted from $O$. sinensis fungus by using CSA/Pyr method with an optimal condition including CSA/Pyr ratio $=1: 3$, at $65{ }^{\circ} \mathrm{C}$ and $6 \mathrm{~h}$. The physicochemical properties of EPS and SEPS $_{11}$ including sulfate and polysaccharide contents, main chemical groups and number of fractions, have been determined to control the quality of sulfation products. Expectedly, our S-EPS derivative reliably improved the $\mathrm{OH}^{\circ}$ and ABTS ${ }^{\bullet}$ radical scavenging potential compared with the natural EPS. However, to evaluate accurately the efficiency of sulfated modification by CSA/Pyr method for boosting the bioactivities of EPS, other bioactive properties such as immunomodulatory and antitumoral activity were performed as well. In conclusion, the sulfated modification of EPS by CSA/Pyr was an effective strategy to enhance its bioactivities so that we can thoroughly exploit the bioactive ingredients of this medicinal mushroom.

Acknowledgements: This work was supported financially by the Young Technology and Science Development Center of Ho Chi Minh city (No 202/HD-SKHCN 20/12/2016).

\section{REFERENCES}

[1] G.H. Sung, N.L.H. Jones, J.M. Sung, J.J. Luangsa-ard, B. Shrestha, J.W. Spatafora, Phylogenetic classification of Cordyceps and the clavicipitaceous fungi. Studies in Mycology. 57, 5-59, 2007.

[2] J.K. Yan, W.Q. Wang, H.L. Ma, J.Y. Wu, Sulfation and enhanced antioxidant capacity of an exopolysaccharide produced by the medicinal fungus Cordyceps sinensis. Molecules, 18, 1, 167-177, 2012.

[3] H.C. Lo, C. Hsieh, F.Y. Lin, T.-H. Hsu, A Systematic Review of the mysterious caterpillar fungus Ophiocordyceps sinensis in Dong ChongXiaCao (Dōng Chóng Xià Căo) and related bioactive ingredients. Journal of Traditional and Complementary Medicine, 3, 1, 16, 32, 2013.

[4] J.K. Yan, W.Q. Wang, J.Y. Wu, Recent advances in Cordyceps sinensis polysaccharides: Mycelial fermentation, isolation, structure, and bioactivities: A review. Journal of Functional Foods. 6, 33-47, 2014.

[5] M.T. Tran, T. Huynh, T.H.L. Thi, M.H. Dinh, Extraction of exo-polysaccharide from the culture fluid Cordyceps sinensis and its effects on proliferation of the peripheral blood mononuclear cells (PBMCs). Journal of Science and Technology, 53, 2015.

[6] P.T. Ho-Thi, T.T. Vu, T. Huynh, M.T. Tran, T.H.L. Thi, M.H. Dinh, Comparison of radicals scavenging activity of exopolysaccharides from cultured Cordyceps spp. isolated in Vietnam. Journal of Science and Technology, 54, 2016.

[7] H. Yuan, W. Zhang, X. Li, X. Lü, N. Li, X. Gao, and J. Song, Preparation and in vitro antioxidant activity of $\kappa$ - 
carrageenan oligosaccharides and their oversulfated, acetylated, and phosphorylated derivatives. Carbohydrate Research, 340, 4, 685-692, 2005.

[8] J. Zhao, S.Q. Wu, B.X. Liu. Studies on sulfated modification of Cordyceps polysaccharide. in New Technology of Agricultural Engineering (ICAE), 2011 International Conference on. IEEE, 2011.

[9] Y. Yu, M. Shen, Z. Wang, Y. Wang, M. Xie, J. Xie, Sulfated polysaccharide from Cyclocarya paliurus enhances the immunomodulatory activity of macrophages. Carbohydrate Polymers. 174, 669-676 2017.

[10] X.T. Ma, X.Y. Sun, K. Yu, B.S. Gui, Q. Gui, J.M. Ouyang, Effect of content of sulfate groups in seaweed polysaccharides on antioxidant activity and repair effect of subcellular organelles in injured HK-2 Cells. Oxidative medicine and cellular longevity. 2017.

[11] Y. Chen, H. Zhang, Y. Wang, S. Nie, C. Li, M. Xie, Sulfated modification of the polysaccharides from Ganoderma atrum and their antioxidant and immunomodulating activities. Food Chemistry. 186 (Supplement C), 231-238, 2015.

[12] L. Wang, X. Li, Z. Chen, Sulfated modification of the polysaccharides obtained from defatted rice bran and their antitumor activities. International Journal of Biological Macromolecules. 44, 2, 211-214, 2009.

[13] S. Li, Q. Xiong, X. Lai, X. Li, M. Wan, J. Zhang, Y. Yan, M. Cao, L. Lu, J. Guan, Molecular modification of polysaccharides and resulting bioactivities. Comprehensive Reviews in Food Science and Food Safety. 15, 2, 237-250, 2016.

[14] X. Zhao, Y. Hu, D. Wang, L. Guo, S. Yang, Y. Fan, B. Zhao, Y. Wang, S. Abula, Optimization of sulfated modification conditions of tremella polysaccharide and effects of modifiers on cellular infectivity of NDV. International Journal of Biological Macromolecules. 49, 1, 44-49, 2011.

[15] J. Zhang, Y. Hu, D. Wang, T. Qin, C. Liu, X. Liu, X. Sheng, S. Chang, Y. Fan, L. Guo, The optimization of sulfation modification conditions for ophiopogonpolysaccharide based on antiviral activity. International Journal of Biological Macromolecules. 51, 4, 657-662, 2012.

[16] T.T. Terho, K. Hartiala, Method for determination of the sulfate content of glycosaminoglycans. Analytical Biochemistry. 41, 2, 471-476, 1971.

[17] W. Zhang, Y. Lu, Y. Zhang, Q. Ding, S. Hussain, Q. Wu, W. Pan, Y. Chen, Antioxidant and antitumour activities of exopolysaccharide from liquid-cultured Grifola frondosa by chemical modification. International Journal of Food Science \& Technology. 51, 4, 1055-1061, 2016.

[18] M. Du, L. Zhao, C. Li, G. Zhao, X. Hu, Purification and characterization of a novel fungi Se-containing protein from Se-enriched Ganoderma Lucidum mushroom and its
Se-dependent radical scavenging activity. European Food Research and Technology. 224, 5, 659-665, 2007.

[19] H. Kim, J. Yun, A comparative study on the production of exopolysaccharides between two entomopathogenic fungi Cordyceps militaris and Cordyceps sinensis in submerged mycelial cultures. Journal of Applied Microbiology. 99, 4, 728-738, 2005.

[20] X. Chen, Z.Y. Ding, W.Q. Wang, K.C. Siu, J.Y. Wu, An antioxidative galactomannan-protein complex isolated from fermentation broth of a medicinal fungus Cs-HK1. Carbohydrate Polymers. 112(Supplement C), 469-474, 2014.

[21] J.H. Koh, K.W. Yu, H.J. Suh, Y.-M. Choi, T.S. Ahn, Activation of macrophages and the intestinal immune system by an orally administered decoction from cultured mycelia of Cordyceps sinensis. Bioscience, Biotechnology, and Biochemistry. 66, 2, 407-411, 2002.

[22] P. H. Leung, S. Zhao, K.P. Ho, J.Y. Wu, Chemical properties and antioxidant activity of exopolysaccharides from mycelial culture of Cordyceps sinensis fungus CsHK1. Food Chemistry. 114, 4, 1251-1256, 2009.

[23] J.K. Yan, L. Li, Z.M. Wang, P.H. Leung, W.Q. Wang, J.Y. Wu, Acidic degradation and enhanced antioxidant activities of exopolysaccharides from Cordyceps sinensis mycelial culture. Food Chemistry. 117, 4, 641- 646, 2009.

[24] G.B. Ding, R.H. Nie, L.H. Lv, G.Q. Wei, L.Q. Zhao, Preparation and biological evaluation of a novel seleniumcontaining exopolysaccharide from Rhizobium sp. N613. Carbohydrate Polymers. 109 (Supplement C), 28-34, 2014.

[25] M. Kozarski, A. Klaus, M. Nikšić, M.M. Vrvić, N. Todorović, D. Jakovljević, and L.J.L.D. Van Griensven, Antioxidative activities and chemical characterization of polysaccharide extracts from the widely used mushrooms Ganoderma applanatum, Ganoderma lucidum, Lentinus edodes and Trametes versicolor. Journal of Food Composition and Analysis, 26, 1, 144-153, 2012.

[26] W.L. Shi, H. Han, G.Z. Chen, X. Chen, Y.K. Hong, L.K. Chen, D. Chen, Z. Lu, Extraction, characterization of the polysaccharide extracts from Se-enriched G. lucidum (SeGLP) and its inhibition against oxidative damage in ischemic reperfusion mice, Carbohydrate Polymers. 80, 3, 774-778, 2010.

[27] A.F.D. Vasconcelos, R.F. Dekker, A.M. Barbosa, E.R. Carbonero, J.L. Silveira, B. Glauser, M.S. Pereira, and M.d.L.C. da Silva, Sulfonation and anticoagulant activity of fungal exocellular $\beta$-( $1 \rightarrow 6)$-D-glucan (lasiodiplodan). Carbohydrate Polymers. 92, 2, 1908-1914, 2013.

[28] Y. Xu, S. Song, Y. Wei, F. Wang, M. Zhao, J. Guo, J. Zhang, Sulfated modification of the polysaccharide from Sphallerocarpus gracilis and its antioxidant activities. International Journal of Biological Macromolecules. 87, 180-190, 2016. 


\title{
Điều chế exopolysaccharide sulfate từ nấm Ophiocordyceps sinensis và tác dụng kháng oxy hóa của chúng
}

\author{
Trần Minh Trang ${ }^{1, *}$, Nguyễn Thị Xuân Phương ${ }^{1}$, Nguyễn Thị Lài ${ }^{1}$, Lê Thị Thúy Hằng ${ }^{2}$, \\ Huỳnh Thư ${ }^{3}$, Đinh Minh Hiệp ${ }^{4}$ \\ ${ }^{1}$ Trường Đại học Khoa học Tự nhiên, ĐHQG-HCM, \\ ${ }^{2}$ Trường Đại học Công nghiệp Thực phẩm Thành phố Hồ Chí Minh, \\ ${ }^{3}$ Trường Đại học Bách Khoa, ĐHQG-HCM, \\ ${ }^{4}$ Ban quản lý khu Nông nghiệp - Công nghệ cao Thành phố Hồ Chí Minh \\ *Tác giả liên hệ: trangbio.hcmus@gmail.com
}

Ngày nhận bản thảo: 21-09-2017; Ngày chấp nhận đăng: 02-11-2017; Ngày đăng: 15-10-2018.

\begin{abstract}
Exopolysaccharide sulfate đã được biết đến làm cải thiện các hoạt tính sinh học. Expolysaccharide (EPS) sản xuất bởi nấm Ophiocordyceps sinensis là một nguồn dược chất tự nhiên. Do vậy, mục đích chính của nghiên cứu này là nâng cao hoạt tính sinh học của EPS thông qua sự thay đổi thành phần nhóm sulfate bằng phương pháp acid chlorosulfonic (CSA) và pyridin (Pyr). Điều kiện phù hợp cho phản úng sulfate hóa được xác định, bao gồm tỷ lệ CSA/Pyr là 1:3 (v/v), và 6 giờ. S-EPS 11 có độ thay thế cao nhất là 1,59 , với
\end{abstract}

thành phần đường tổng và sulfate lần lượt là $52,25 \%$ và $47,15 \%$. Bên cạnh đó, phân tích FT-IR chứng minh $S-E^{2} S_{11}$ có sự hiện diện của dao động dãn C-O-S $\left(\mathcal{o}^{3} 815 \mathrm{~cm}^{-1}\right)$ và $S=O\left({ }^{\circ} 1129 \mathrm{~cm}^{-1}\right)$, trong khi EPS không hiện diện những dao động này. Đặc biệt, khả năng bắt gốc tự do $\mathrm{OH}^{\bullet}$ và $\mathrm{ABTS}^{\bullet}$ của S-EPS 11 tăng lên đáng kể so với EPS không sulfate. Kết luận, chúng tôi đã tổng hợp thành công dẫn xuất exopolysaccharide sulfate từ nấm $O$. sinensis với hoạt tính kháng oxy hóa được cải thiện rõ rệt.

Index Terms-Ophiocordyceps sinensis, exopolysaccharide, sulfate hóa, kháng oxy hóa, phân tích FT-IR 